\title{
Analysis of the sustainability level of the natural-territorial complex of the city of Tyumen
}

\author{
Marina Podkovyrova ${ }^{1, *}$, Anatoliy Oleynik ${ }^{1}$, Olga Volobueva $^{1}$, and Anastasia Larionova ${ }^{2}$ \\ ${ }^{1}$ Industrial University of Tyumen, Volodarsky Street, 38, 625000, Tyumen, Russia \\ ${ }^{2}$ Magellan, LLC, Tyumen, Russia
}

\begin{abstract}
In this article, the authors present the results of the analysis of the key components of the natural-territorial complex (NTC) of the city, or the territory, natural, and natural-economic systems of the city. Under the conditions of urban development of the territory, the natural-territorial complex of the city undergoes anthropogenic impact, existing natural systems are modified, internal interconnections are broken, new ones are being formed for the purpose, content and functioning of natural-economic systems, and natural and anthropogenic risks can be manifested. The current conflict between natural and anthropogenic subsystems requires a comprehensive and integrated approach to their assessment $[1,2,3,4,5,6$, 7]. The authors proposed a methodology according to which the level of sustainability of the natural-territorial complex of the city of Tyumen in terms of its urbanization is determined. The methodology includes a hierarchy analysis method, a comprehensive assessment, cluster analysis, sociocultural research, a cartographic method, and a modeling method [5, $8,9,10,11]$. The analysis includes ten planning areas (districts) of the city: Bereznyakovsky (1), Tarmansky (2), Parfenovsky (3), Zatyumensky (4), Zarechny (5), Central (6), Gilevsky (7), Verkhneborsky (13), Mysovsky (14), Novoroshchinsky (15). The assessment is presented in more detail on the example of two districts - Central and Zarechny (Fig. 2).
\end{abstract}

\section{Introduction}

The natural-territorial complex of the urbanized landscape of the city of Tyumen is formed and develops under the influence of historical, economic, social, landscape and planning conditions, often losing or worsening the state of its key components, that is, natural components, thereby reducing the level of both environmental and socio-economic sustainability of urban land use.

Based on the goals, the following tasks were solved:

1. The theoretical foundations of the natural-territorial complex of the city were investigated.

2. The purpose of a comprehensive assessment of the natural-territorial complex of the city is determined, a methodology is developed, factors, indicators and assessment methods are substantiated; scales of levels of variability of the city's NTC are developed, which

\footnotetext{
* Corresponding author: podkovyrova.54@mail.ru
} 
reflect the degree of the city's sustainability and vulnerability of the geosystem under investigation $[2,13]$ :

3. The results of a comprehensive assessment are presented and a model for further maximum possible sustainable development of the city of Tyumen is proposed.

A comprehensive study of the variability and sustainability of the city's NTC was carried out according to the following factors $[1,2,6,8,10,13]$ :

1. Socio-economic (level of variability: of general parameters of the city, social and economic activity in the city, resource consumption, public health, conditions of housing stock; level of development of the sphere of social, cultural and public services, transport support of urban areas).

2. Environmental (level of atmospheric air pollution, territorial differences of soil natural, anthropogenic and man-made pollution and changes in the state of floodplains) [2, $11]$.

3. Urban planning (functional organization of the territory; the level of variability of the territory in terms of architectural and aesthetic qualities and technical and economic indicators that characterize the development and engineering arrangement of the city).

4. Landscape and aesthetic.

\section{Results and discussion}

The results of the socio-economic assessment showed that in terms of the number of people living in planning areas, the population prevails in Planning area 6 (Central) (Fig. 1). In this planning area, the population density is 336 people per 1 ha, which significantly exceeds the value of this indicator in the 1 st and 15 th planning areas.

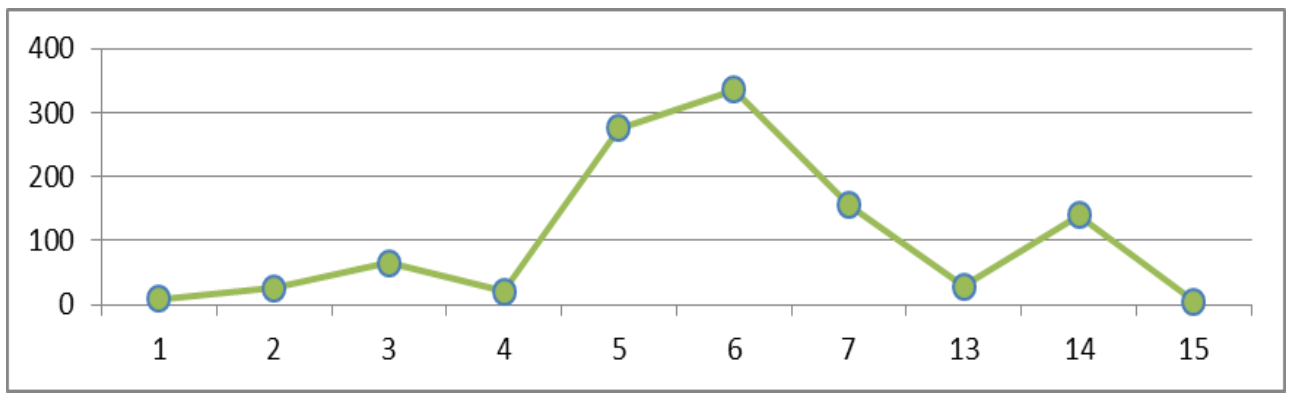

Fig. 1. The population density within the boundaries of the residential area, people / ha. 


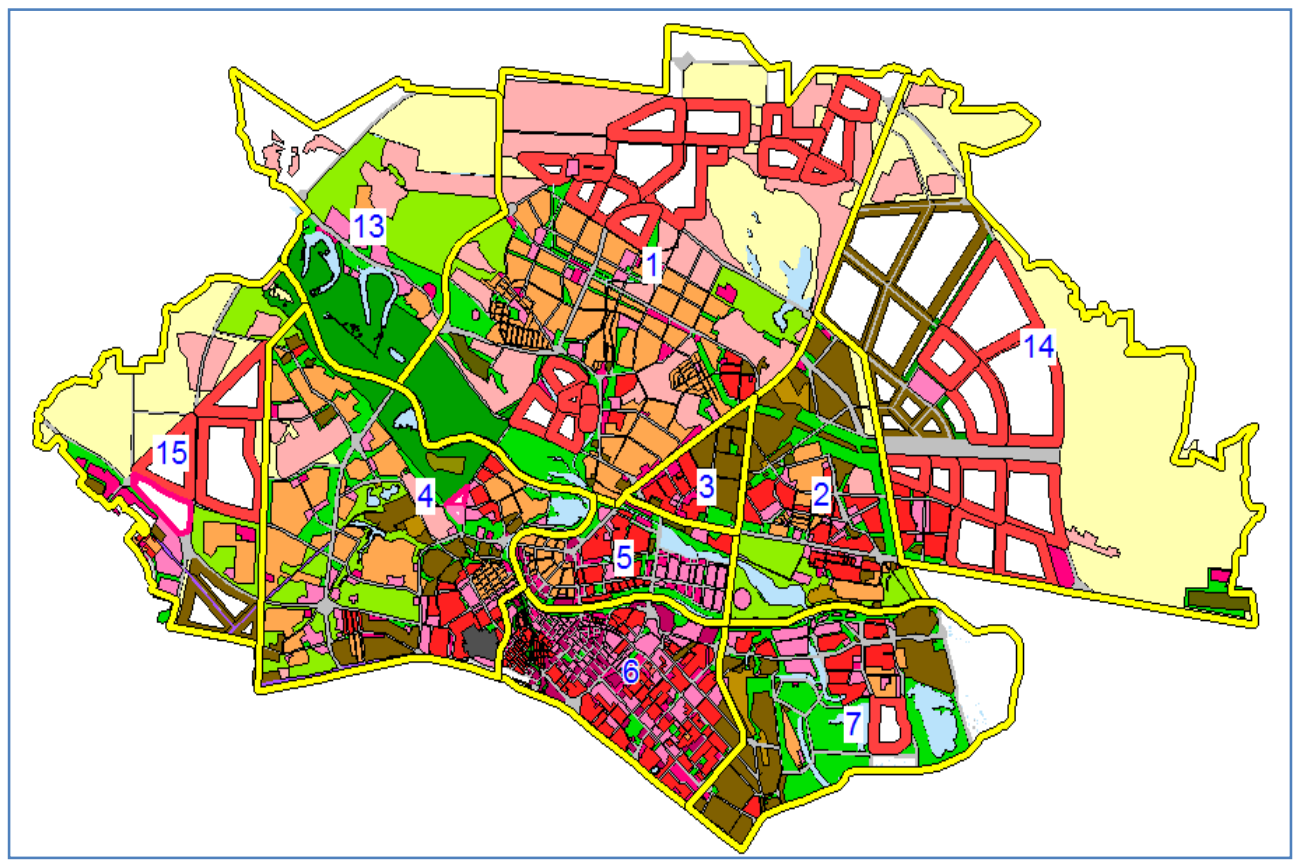

Fig. 2. The planning areas of the city.

In the Central district, the building density coefficient is 0.7 , which is significantly higher than in Planning areas 14 and 15 (0.04), see Fig. 3.

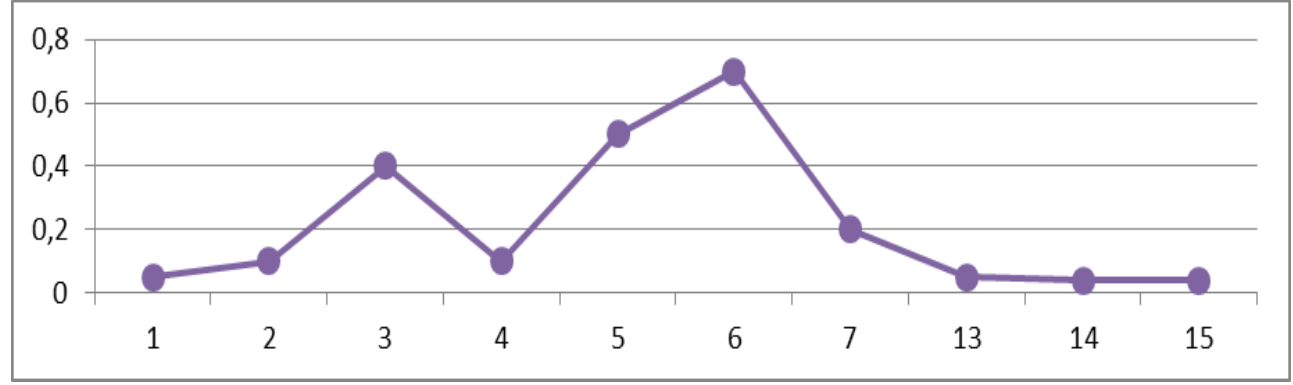

Fig. 3. Building density coefficient, $\%$ of the total territory of the city.

There is no multi-story residential development in Planning district 13, the highest density of multi-story residential development is in the Central planning district, and the lowest is in Planning areas 15 and 3. In Planning district 14, the highest density is in the areas with low-rise buildings, and individual residential development prevails in Planning areas 1 and 15, and is absent in Planning areas 3, 6 and 13 .

The environmental state of the city is influenced by the presence of industrial and municipal facilities (Fig. 4-5). 


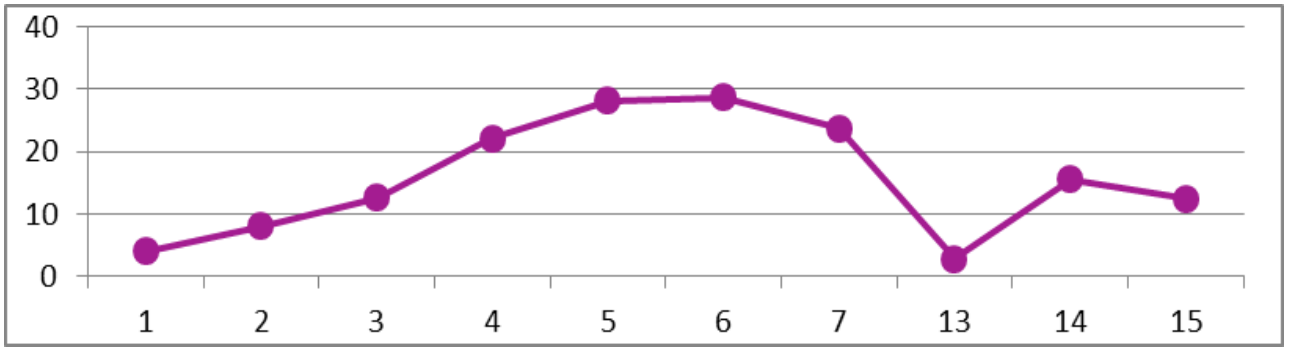

Fig. 4. Public and business development, \% of the total territory of the city.

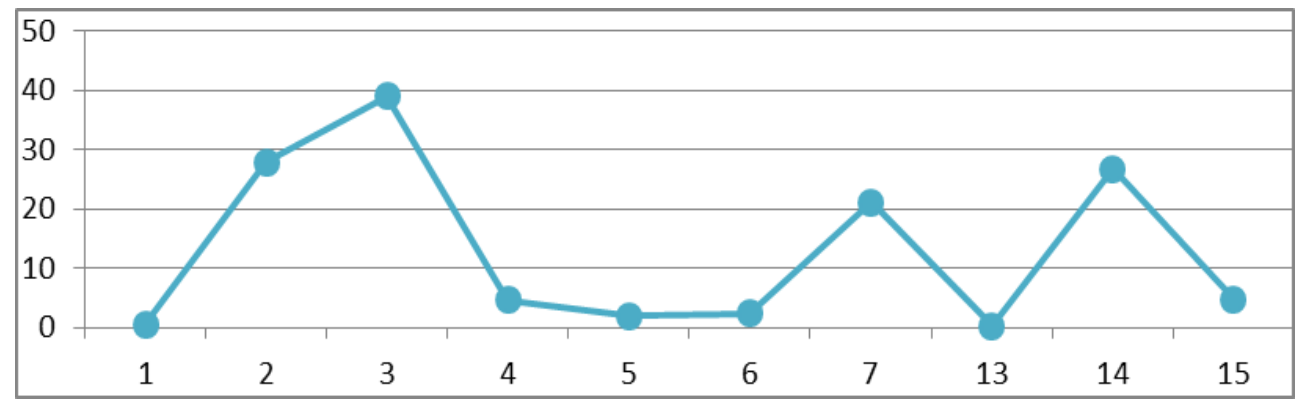

Fig. 5. Industrial development, $\%$ of the total city area.

As for the ecological and landscape-aesthetic state, the Zarechny planning district is characterized by the least degree of variability or the highest degree of sustainability (IV$100 \%$ ), the Central planning district is characterized by III and IV degree of variability (Tables $1-2$ ).

Table 1. The level of NTC variability of estimated planning districts of the city according to landscape-aesthetic conditions.

\begin{tabular}{|c|c|c|c|c|}
\hline \multirow{2}{*}{ Indicator } & \multicolumn{4}{|c|}{ Evaluation score } \\
\cline { 2 - 5 } & \multicolumn{2}{|c|}{ Zarechny planning district } & Central planning district \\
\cline { 2 - 5 } & Green area & Residential area & Green area & $\begin{array}{c}\text { Residentia } \\
\text { 1 area }\end{array}$ \\
\hline Landscaping level & 5 & 4 & 3 & 2 \\
\hline Distance from the center & 8 & 9 & 1 & 1 \\
\hline Cultural heritage preservation level & 6 & 3 & 6 & 6 \\
\hline The level of terrain scenic beauty & 3 & 5 & 8 & 7 \\
\hline $\begin{array}{c}\text { Panorama of the surrounding open } \\
\text { spaces }\end{array}$ & 6 & 5 & 5 & 4 \\
\hline $\begin{array}{c}\text { The level of compositional } \\
\text { advertising load }\end{array}$ & 10 & 9 & II & IV \\
\hline The degree of NTC variability & II & II & low III - IV \\
\hline $\begin{array}{c}\text { The degree of sustainability of the } \\
\text { NTC }\end{array}$ & \multicolumn{2}{|c|}{ high I - II } & & 8 \\
\hline
\end{tabular}


An environmental assessment took into account the degree of soil pollution with heavy metals. Sources of pollution are the road transport complex (Table 2, Fig. 6-7), industrial and municipal waste.

Table 2. The level of the NTC variability of estimated planning districts of the city by technical and economic indicators.

\begin{tabular}{|c|c|c|c|c|}
\hline \multirow{2}{*}{$\begin{array}{c}\text { Planning } \\
\text { district }\end{array}$} & $\begin{array}{c}\text { Population density, } \\
\text { [people/ha] }\end{array}$ & $\begin{array}{c}\text { Development density } \\
\text { (density factor) }\end{array}$ & $\begin{array}{c}\text { Density of the } \\
\text { road network, } \\
{\left[\mathrm{km} / \mathrm{km}^{2}\right]}\end{array}$ & $\begin{array}{c}\text { Level of } \\
\text { NTC } \\
\text { variability }\end{array}$ \\
\hline Zarechny & 77.0 & 0.5 & 1.7 & II \\
\hline Central & 111.0 & 0.7 & 2.8 & III \\
\hline
\end{tabular}

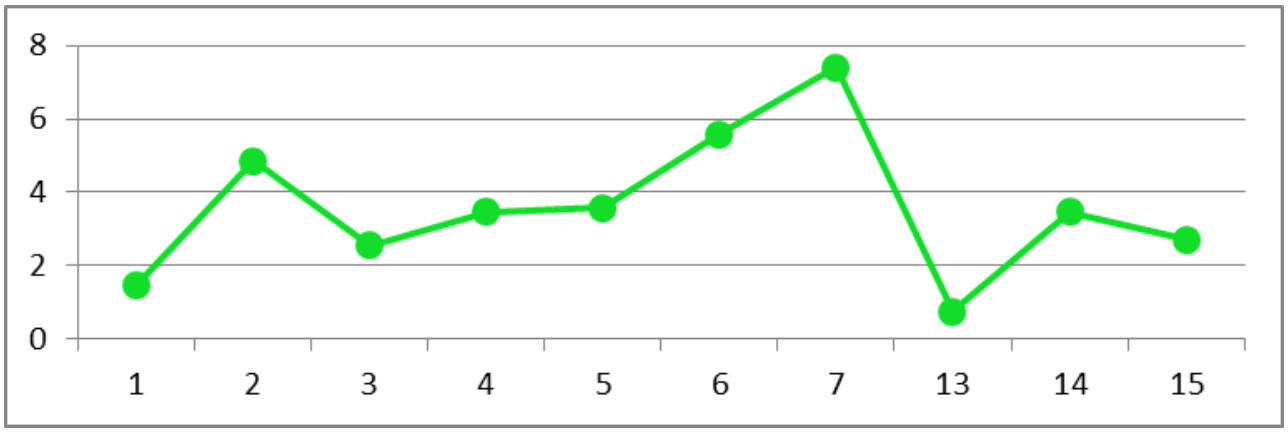

Fig. 6. Zone of transport infrastructure, $\%$ of the total territory of the city.

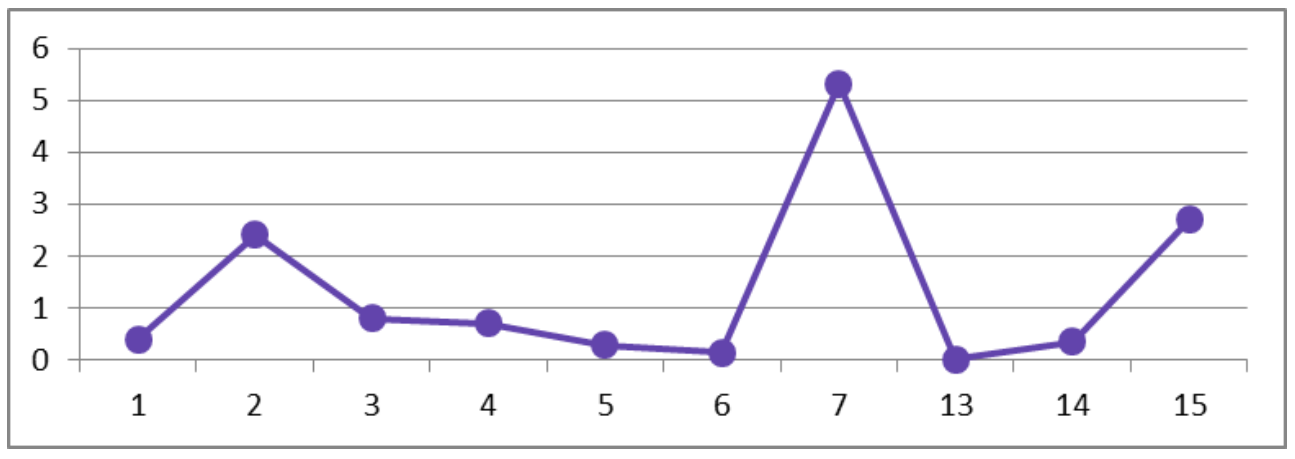

Fig. 7. Zone of engineering infrastructure, $\%$ of the total territory of the city.

To identify territorial differences in the established levels of variability and sustainability of the NTC of the planning areas of the city, the method of cluster analysis and thematic mapping was used (Table 3, Fig. 6). Zarechny planning district was included in four clusters with relative environmental favorability of the territory (Clusters 1, 40, 41, 46). The Central district includes 14 clusters, of which Clusters 12, 37, 42, 53 characterize the territory as environmentally friendly; Cluster 5 includes land plots with environmentally unfavorable conditions; $35 \%$ of the district's territory is included in the zone of relative environmental friendliness (Fig. 8). 


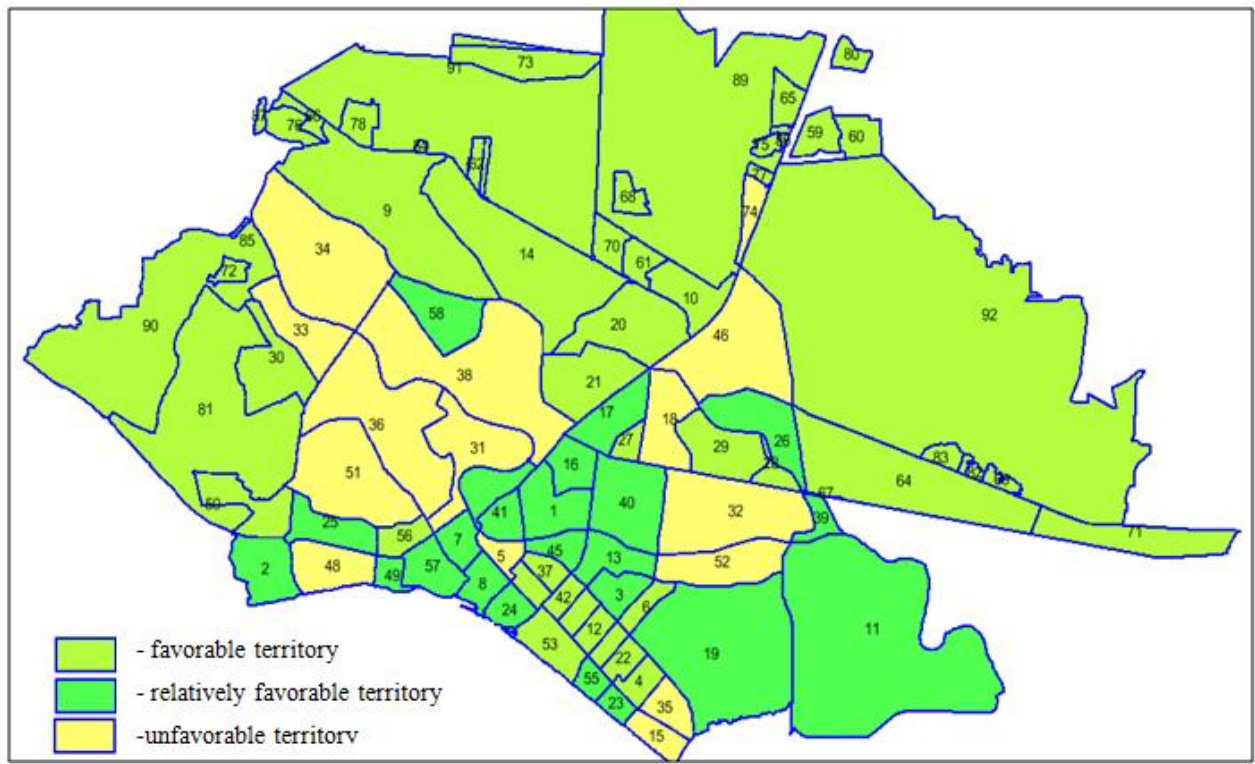

Fig. 8. Results of a comprehensive environmental assessment.

\section{Conclusions}

The study revealed that various levels of NTC sustainability were formed in the Zarechny and Central planning districts, influence factors were determined, as well as possible directions in the field of formation of the most sustainable development of the city.

The analysis of the sustainability level of the NTC of the city of Tyumen determined that:

1. The Central planning district, as a historically established city center, is undergoing a greater degree of change in almost all components of the NTC. It is proposed to expand the area of green spaces due to the demolition of dilapidated housing of accident rate III and IV $(15.7 \%$ of the area) and landscaping of the coastal water protection zone.

2. The Zarechny planning district has the flexibility to plan the development of its territory, which will allow solving a number of problems due to the engineering and landscaping of the territory: the creation of the embankment (the left bank of the Tura River) and the demolition of dilapidated housing of accident rate III and IV in its southwestern part $(20,5 \%)$.

3. There are options for preserving and improving the unique floodplain areas of the city, which have undergone a number of changes due to the regulated river flow of water bodies, as well as the disseminated state in urban development. In this connection, it is proposed to optimize the landscape structure of the city, to include the territories of the floodplain landscape in the system of the natural and ecological skeleton of the city of Tyumen with the subsequent creation of recreation zones, removal of dilapidated housing, and the organization of linear green spaces; preservation of the historically established compositional-spatial connection between the city center located on a high bank and an open panorama of the floodplain landscape $[1,6,11]$.

4. The process of forming sustainable urban land uses (geosystems) is impossible without the implementation of integrated monitoring of soils, the pollution of which is related to the influence of man-made systems (urban industrial and transport facilities), 
which will make necessary adjustments to the existing master plan of the city and ensure comfortable living conditions of people $[7,12,13,10]$.

\section{References}

1. M. A. Podkovyrov, A. M. Oleinik, A. A. Matveeva, International Journal of Civil Engineering and Technology, 9, 513-521 (2018)

2. Z. G. Mirzejanova, E. M. Climina, Academy of Sciences, 4, 255-63 (2007)

3. D. Veteikis, P. Kavaliauskas, R. Skorupskas. D. Veteikis, P. Kavaliauskas, R. Skorupskas, Landscape and Landscape Ecology, 348-358 (2015)

4. S. J. Pollard, UNESCO Encyclopedia of Life Support Systems, 285-289 (2008)

5. M. A. Podkovyrova, O. N. Volobueva, L. N. Gilyova, E3S Web of Conferences, 110, № 02114 (2019)

6. A. Ishizaka, A. Labib, ORinsight, 24, 201-220 (2009)

7. G. W. Suter II, Integrated Environmental Assessment and Management, 285-289 (2008)

8. V. Belton, T.J. Stewart, 374 (2003)

9. M.A. Podkovyrova , N.S. Ivanova, Article (2019) doi: $\underline{10.32651 / 1911-80}$

10. G. Zelian, Ню Yecui, Z. Xinqi, Article, 91, 104369 (2020)

11. L. T. Krupskaya, A. V. Leonenko, V. P. Zvereva, Contemporary Problems of Ecology, 6, 223-227 (2013)

12. M. A. Podkovyrov, A. M. Oleinik, Collective Monograph, 44-56, Penza (2019)

13. T. Durrant, R. Hiedever, Environmental monitoring, 11, 774-781 (2009) doi: $10.1039 / \mathrm{b} 818274 \mathrm{~b}$ 